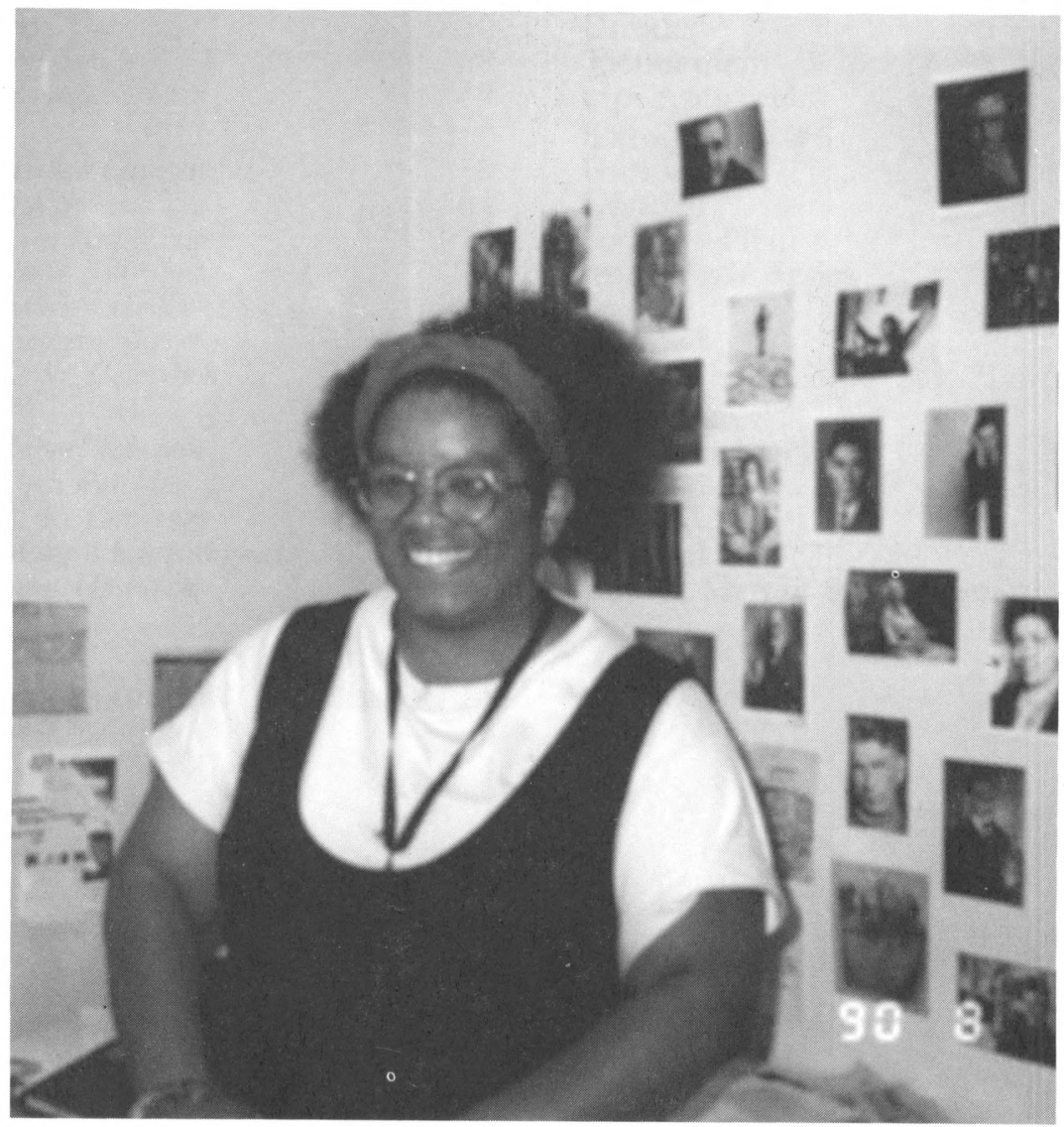




\section{INTERVIEW WITH MICHELLE COLLINS}

\section{Mary Collins}

Michelle COLLins HaS taught at Louisiana State University and here at the University of Iowa. While here, she taught courses on black women writers and lectured on womanism, as well as being involved in the local community. She is now teaching at Earlham College. In the following interview, she discusses womanism, her own particular vision for black women today, and her vision's implications for literature and society as a whole.

Let's start with "womanism." I have Alice Walker's definition here. The first one she gives is "the opposite of girlish, acting womanish." The second one is "a woman who loves other women, sexually and/or non-sexually. Appreciates and prefers women's culture, women's emotional flexibility (values tears as natural counterbalance of laughter), and women's strength. Sometimes loves individual men, sexually and/or non-sexually. Committed to survival and wholeness of entire people, male and female. Not a separatist, except periodically, for health. Traditionally universalist." And then she gives two more: "Loves music. Loves dance. Loves the moon. Loves the Spirit. Loves love and food and roundness." I love that definition. And finally, "Womanist is to feminist as purple is to lavender." Would you comment on that definition?

I like it. It's one I've used myself. I still haven't figured out this "Womanist is to feminist as purple is to lavender." . . One of the things I like about it is that it is very all-inclusive and all embracing. I think that one of the reasons why Walker and other women of color who are interested in what we traditionally call feminism have explored alternative definitions is because feminism has been a kind of exclusive and exclusionary club. Certainly, as it has been practiced 
in the U.S. it's been a movement principally of pretty comfortable middle-class white women, reflective of those values.

Women who had the time to worry about it.

Exactly. Women for whom, say, the definition that work is liberating made a great deal of sense because they're thinking about work in terms of becoming a lawyer, becoming a doctor, becoming a CEO of a major corporation.

For a lot of women of color in this country, work is not liberating. Work is precisely what they wanted to get away from because they had always worked.

And for lower-class white women-or even lower-middle-class. I was a legal secretary for two years, and I tell you, the majority of the women working there as secretaries were doing it for survival.

Right. To be a secretary would be quite a nice job. We're talking about women for whom working meant cleaning other people's toilets, taking care of their kids, washing their dirty clothes, cooking their food. Not the kind of work that's liberating. Not the kind of work that brings you to a better consciousness of yourself as a being of worth in the world.

So right there, in terms of that one slogan, and that one set of values that is embodied in feminism, you get a serious cultural disjunction.

I think that what Walker is doing with the womanist aspect is trying to expand or create a definition that would include women-women who love men, women who love women, women from all kinds of cultural backgrounds who share, I think for her, a certain spiritual orientation.

I was struck by the inclusiveness of her definition. It includes black lesbians. It includes everyone who loves music and loves dance and loves the moon. I really like the definition myself-it's explicitly not separatist.

Right. One of the things that's been off-putting in terms of the traditional women's movement is this idea, or this connotation, of a certain separatist element. When you're dealing with two kinds of oppression, oppression in terms of gender and oppression because of race or color, then that kind of separatism of women from men becomes increasingly problematic because both black men and women 
share a kind of oppression that white men and women don't share. That allows for another culturally specific aspect of black experience that traditional feminism does not.

That connects with Ogunyemi's definition. She says that "the intelligent black woman writer, conscious of black impotence in the context of white patriarchal culture, empowers the black man. She believes in him; hence her books end in integrative images of the male and female worlds." She never explicitly states that you have to be heterosexual to be a womanist, but I certainly got the impression that if you were a black lesbian, you were on the fringes of womanism, if you were included at all, because you aren't participating in that black community.

Lesbians have had, I think, a kind of peculiar status in the black community. There tends to be, for a variety of reasons, much more hostility to homosexual women than there has been to homosexual men. Of course, our culture is a pretty heterosexist culture all the way around. I think that in a curious conjunction with this kind of association of feminism with separatism there tends to be that public perception of feminists as lesbians. Whether or not that's actually the case for the bulk of feminists in this country-if you know anything about some of the tensions in NOW, you know that lesbians were not in great standing there-part of the problems with black women in the white feminist movement is this perception of a necessary hostility towards men, a necessary separatism that's coupled with lesbianism either as a political stance or as a personal sexual preference. So you get a similar hostile response to what you might get from the mass of white women who might not want to be identified as feminists, because they're aware of that same connotation.

I still remember when I was a graduate student teaching a course on men, women, and utopias and we had been talking about Herland, a feminist utopia. Shortly thereafter, I was at some public event, and I ran into some of my students. I was there with the man I was seeing at the time, and I could just sort of feel the rustle in the background. "Did you see that! She's with a man! I thought she was one of those ... Well, she says she's a feminist." And you could just sort of see the consternation. Clearly, in their minds, feminist and lesbian were connected, and they were really quite upset to find their stereotype challenged. I think it's true that feminism has been around long enough that there are stereotypical feminists, people think they know what a feminist is, and they are constantly expressing surprise when they meet a feminist who, I don't know, doesn't wear jack boots. I had somebody say to me once, "You aren't really a feminist, are you, 
Michelle? You do seem to love children so much." I wasn't aware that the two are mutually incompatible.

We project stereotypes all the time. I think we only tend to think about them when we think about the classic battles of stereotypes. We are sensitized culturally to know that certain stereotypes are bad and they shouldn't happen, but we're not generally analytical enough to think of the kinds of categories that we keep in our minds in order to be able to identify people one way or another.

All these definitions of womanism are really trying to break out of that mold, break out of that way of looking at people more as objects than as subjects and being able neatly to fit them into all kinds of categories or definitions. One of the things that Walker's definition focuses upon is more a mode of behaving, or thinking, or feeling about things and relationships than a certain static way of being.

It does seem very dynamic, the way that Walker presents it.

Bell Hooks makes an interesting suggestion. She suggests that rather than saying, "I am a feminist," a person should say, "I advocate feminism," because that identifies her, in her mind, as advocating a certain set of political ideas, probably revolutionary ideas, rather than grounding the movement in some kind of essential being that you identify yourself with. I think that Walker's definition goes beyond that essentialism into something else, which I think is a good thing.

I would agree. Ogunyemi also says that "If the ultimate aim of radical feminism is a separatist idyllic existence away from the hullabaloo of the men's world, the ultimate aim of womanism is the unity of blacks everywhere under the enlightened control of men and women. Each is finally separatist, the one sexually, the other racially - and their different goals create part of the disunity in the women's movement."

One of the things that I think is valuable about Walker's work in general, and that definition in particular, is that it is a very conscious effort to break out of that kind of oppositional hierarchy-black versus white, men versus women, poor versus rich-into something, whatever the opposite of oppositional is. What liberal feminism did, what we tend to categorize as liberal feminism did was not to look at the basic political, social, sexual, hierarchical structure of this culture and try and change it, but, instead, simply to assert that women were just as good as men and should share in the privileges that men have, as opposed to looking at a system that allows some small minority a 
certain degree of privilege at the expense of the majority. What was radical about the radical feminists as opposed to the liberal feminists is their saying that we want to turn our backs on the system and create our own someplace else. I think that she is attributing the same sort of [separatist] impulse to womanists, to the degree that they exist as a conscious and identified group: "we're going to turn our backs on this white patriarchy, and we're going to create our own intimate space of color." There may be nothing wrong with withdrawing oneself within a culture, particularly if one feels powerless to completely transform it, and start over from scratch someplace else. But I think that in both instances, if you are going to identify the people who are going to do this withdrawal according to some intrinsic quality-either their gender or secondary sexual characteristics, or the color of their skin - then again here we're posing a certain kind of essentialism, that kind of essentialist feminism that says, if women ran the world, the world would be a better place, because women are much nicer people than men. To which I always want to say, "What about Margaret Thatcher? She's a woman, she is running Britain, and she is not a nice person!" Why isn't she a nice person? Because it does not have anything to do with what gender you are and has everything to do with the values which are inculcated into you. Margaret Thatcher as woman is just as much of an imperialist as any man could be. By the same token, it's a kind of reverse racism, or a kind of essentialism, that says that black people are just much nicer than white people, and if black people were running the world, it would be a wonderful place.

So you would reject Ogunyemi's definition?

Yes.

\section{Would you have anything to add?}

Well, it's a nice dream. [laughter] We all have these days, and I think Walker accounts for that very nicely. Occasionally, for reasons of health, there are times when we all need to withdraw and be separate, but that's not a principle upon which to build a civilization, not unless you want to repeat the same mistakes over and over again.

Do you have anything to change or add to Walker's definition? Or could we say that that is your definition too?

I pretty much like it. It doesn't require that I give up anything of which I am fond. [laughter] As I recall, there is a bit in there where she talks about the African race or the black race being like a garden of 
flowers where women come in every conceivable color. That, in and of itself, allows for even more inclusion as opposed to exclusion. I suppose that's what I would hold my basic principles to be, inclusionary rather than exclusionary.

Well, as long as we are talking about inclusion, now I get to ask the question I really want to know, because I am very attracted to this idea of womanism and what it all means. Can I, as a white woman, be a womanist?

Oh, I should think so.

Well, in Ogunyemi's article ...

Well, no. You couldn't according to her definition.

But I can according to Walker?

I think so. This strikes me as particularly true if you look at the evolution of her work. One of the things that is quite remarkable about The Temple of My Familiar, and quite disturbing to a lot of folk, is that it doesn't set up unique categories. You have a variety of different kinds of relationships, sexual and otherwise. The principal characters are not all black, in fact most, if not all of them, are of mixed raced, which I think in many ways reflects the ideal that she sets up in that definition. And she wrote that definition years before she wrote the novel.

Again, it's a way of behavior, a way of looking at the world, a philosophy of life, as opposed to being grounded in what gender you are or what color your skin is. I think if you asked Walker, she would probably want to say that there are certain ways of behavior which are better than other ways; there are certain cultures that are more inclusive than other cultures. And, I think, there is a certain degree of unity on the issue of white patriarchal culture as being bad, not bad because it is the creation of white men, who are themselves inherently bad-[laughter] maybe they are, maybe they aren't-but more because of the kinds of principles and values that it extols.

Western white patriarchal culture is grounded on the politics of exclusion and opposition. It's white men saying, "We are good and you are bad. You are bad because you are not like us. It's not that there are two sexes; there is really only one sex and then one that is pathological or flawed. There are really only men and castrated men, but not men and women." To borrow an image from Morrison where 
she describes the white slavers as the men without skins-there are really only people with skin and people who don't have skin. Good people and demons. That's the politics of exclusion, the politics of opposition.

And if you're being inclusionary, then it doesn't have to do with judging people according to their physical being, the presence or absence of certain secondary sexual characteristics, the presence or absence of a certain amount of melanin in the skin. It has much more to do with the way people behave towards each other, the kinds of values that they embody.

So, it is much more a spiritual thing?

Yes, I think so. It has to do with how you relate to other people, animals, and things on the planet. And one of the things which you see running throughout Walker's work, and this is characteristic of a lot of third world peoples, or however you want to describe them, is a sense of the world in which virtually everything, things which we in Western culture would think of as things, objects-plants, animals, rocks, the earth itself-all these are imbued with spirit and need to be treated with respect. Which means they are treated as kindly as you would treat another human being or subject that can speak to you in the same language that you yourself speak.

Do you think that white feminists have become more attuned to black women's needs and are better representing them?

Speaking from my own experience, we still have a long way to go. I have seen some changes. Unfortunately, I think I have seen most of those changes outside the academic world, which is kind of sad. It's kind of hard to maintain a radical perspective, radical in the sense of wanting to change things fundamentally, at the very heart of the organizational principles, once that system has embraced you. You have an investment. And of course, it's like it's a new fad, the new academic fad. You want to have a womanist or a person of color. Everyone wants a black woman on their faculty.

How do you think womanism is being integrated into the university? Do you think it ought to be integrated into the university?

I would like to see the entire university restructured, according to more womanist, inclusionary lines. I think there is an up side and a down side. Yes, the fad is good for a lot of reasons. A lot of people who 
had a hard time getting jobs are going to have a relatively easier time. Because there is a demand-there are more people who want a woman of color or a certain kind of theorist on their faculty - they'll be able to make better deals for themselves and not strictly in a monetary and venial sense. They might be more comfortable than they might otherwise have been.

But then the down side is that you may very well end up being the only one. You're the one who is expected to heal the rifts, if there is tension between women of color and white women feminists on campus. That's a tremendous burden. The other thing you tend to see when there are fads is that you bring somebody in, you keep them around for three to five years, they work themselves really hard, tenure time comes around, and you say, well, bye. The fad's over.

The problem with fads is that you're looking for somebody who does something, and yet, at the same time, I think in the back of people's minds is the sense that nothing will really change. They will hire these new people, there will be this new viewpoint represented, and life will just roll merrily along.

It gets back to what you were saying about the radicalism being subverted once you have an investment. How do you think the radicalism can be preserved?

I don't know. For myself, as you might know, they offered me a job here and I did not take it. One of the reasons that I didn't take it is that I was offered a job at a school that is really much more reflective of the principles and ideals that I hold dear. I don't know if anyone has ever described Earlham college as a womanist kind of place. It's a Quaker school in Indiana. This is a place that, I think, has people who are in fact working very hard to institute a kind of ideal educational community that is inclusive rather than exclusive, that is nonhierarchical to the degree that you can run a college in nonhierarchical terms. And this is very attractive to me.

[Also,] The University of Iowa is a research institution, and the reality of life at a research institution is that if you want to be promoted, if you want to get tenure, then your principal responsibility is research and writing. That is what you are going to get rewarded for. That is what is going to count the most in your evaluations. Teaching becomes secondary. It's nice, people want you to be a good teacher, but if you're a really terrific teacher, and you haven't published the requisite number of articles and the requisite books at the end of five years, it's going to be good-bye. Whereas at your typical liberal arts 
college, at Earlham at least, there is more of a balance between research and teaching. It defines itself in terms of its principal function to act as a teaching institution. Research and teaching do go hand in hand. I don't think you can be a good teacher if you are basically teaching the same ideas that you had when you were a graduate student, if you are not constantly engaging with new theories and new ideas and new positions. That's what scholarship is about, that's what the writing is about, that's what the research is about.

Given a choice between working where the kind of teaching that I want to do is actively encouraged, is rewarded, and working at a place where "That is so nice, we're so glad that you're doing this, but if you don't have that book written, sorry, we can't give you tenure," it's much more sensible to go to the other place than to stay here. Books are going to be read by maybe a couple of hundred people. Teaching however many people I can teach over the course of the rest of my career and teaching them in conditions which allow me to teach what I think is important for me to teach strikes me as much more beneficial. Because then they can go out and become presidents, governors, senators, heads of corporations that are organized under different principles.

The other thing, and I am not sure if this is an institutional problem or what, is that, at an institution where there are not many people of color and even fewer women of color and yet there is a lot of interest in promoting diversity, there are just too many demands made on your time. You say no too often. Just during the course of this year I have had a great time and done a lot of interesting stuff-given lectures, attended panels, worked with students and what not-but a lot of these activities are things that I wouldn't have been able to do if I had been on the clock and worried about tenure. These are things I could do because I was a visitor. Here today gone tomorrow. You are really put into an impossible situation, as you are expected as one person to do the work of ten or twenty. As I look at the current state of affairs in this country-in terms of race relations, in terms of education, in terms of a lot of things-I think we are going to hell in a hand basket. I think that race relations are at a new all-time low. We have people being lynched. There are fewer minority students going to colleges and universities, getting advanced degrees. We are in pretty bad shape.

Why do you think this is happening? 
Certainly, eight years of Reagan didn't help, but we can't blame everything on Ron, tempting though it may be. But what he did do is he made people feel comfortable about their own institutionalized racism, sexism, homophobia. Nikki Giovanni put it very well when she was here. We kind of thought that if we went to white people and said, "No, we really don't appreciate being treated this way," they would say, "Oh, we didn't realize. We're so sorry. Let's change it all." That didn't happen. Reality is, at least in questions of race relations, in some ways it's pretty simple. African-Americans have been in this country for almost four hundred years. Of that four hundred years it's only been a hundred and twenty-five or so since the emancipation. And even then didn't blacks only count as three-quarters of a person, or two-thirds? You still had to get the amendments to the constitution to allow black men to vote, a whole host of laws in support of equal rights. In point of fact, if you date things, say, from the civil rights acts of '64, we are really talking about twenty-five years. That's a very, very short period of time. It's not even quite a generation. And I think that people forgot that twenty-five years ago there were good, upstanding citizens screaming, spitting on black children who were integrating schools, ready to let loose police dogs at them, shooting people, killing civil rights workers. Twenty-five years ago that was happening. And in twenty-five years you can't even count on all those people dying [laughter], much less rooting out all the institutionalized race hatred.

It has always been my impression that this gets progressively better. But then I encounter students who are back with my grandparents when it comes to race relations, and that really scares me. Though twenty-five years is not a long time, it doesn't seem to be progressing anymore.

Well, we are kind of assuming that everyone during that twenty-five years was doing a lot of soul searching, class and race analysis. In general, people just don't do that. They don't analyze themselves and their attitudes. They don't think about the political ramifications or the ideological underpinnings of their behavior. We have had twentyfive years of consciously working to ameliorate race relations in this country. We have had twenty-five years of people saying, "Well, we have laws about that now, so it's fixed."

You could talk to all kinds of people and not come up with one who would [say] that mom and dad sat them down and said, "Black people are really terrible people. In fact, they're not really human beings at all. They are taking away the things that are rightfully ours and we have got to do something about it." Now, I suppose that if you grew up in a family that is traditionally a member of the Klan, these are the 
sort of lectures that you might get. But for the vast majority of white Americans in this country, they didn't get that lecture. They may never have met a person of color in their lives and yet they will be very upset if a black family is going to move into the neighborhood. They will be very upset about integrating the schools.

That whole idea that they're taking away something that is ours is resurfacing with the reverse discrimination issue. What is your reaction to that?

It's part of the culture. You have to realize that if you're going to change the system, the people who have the most invested in the system are going to lose something. Now you may believe, as I firmly do, that they are going to gain something as well. But what they are going to gain may be of a different order than what they are going to lose. If they are going to lose a certain kind of security they are not even aware that they had, then it comes as a kind of personal threat. The clearest example of this is when you listen to interviews of whites in South Africa, and they say, "They want what we've got, and it's not fair that we have to give it up." From their way of looking at the world, it is not fair because it is theirs. And they know that they're superior. So why should you be asking them to give up what's theirs to people who aren't quite human in their definition? It seems totally unreasonable. If you can put yourself in that position, it might seem pretty unreasonable to you as well. So what you may need to do is change their way of thinking. That there are white people in South Africa who are against apartheid strikes me as miraculous in the extreme, because they have somehow managed to grow up with a radically different vision of the world, to make a huge leap.

This is why I think that teaching is so important. That's the work that teachers do, that's the work that is supposed to happen at colleges and universities. But you have to take the time. Teaching is a very time and labor intensive business with no immediately visible results. Occasionally, you will have a student who will come to you at the end of the semester or write to you years later, "Well, you know, I finally got it, it finally clicked. What you did in that classroom has really changed the way I look at the world and behave in the world." Maybe. Maybe it happens more often than we know; we just never hear about it. It's not like building cars or doing something where you have an immediate, tangible product, and yet it is the only way that change can occur.

If we had been working for the last seventy-five years on how we think about race, what our attitudes are toward people based on their 
wealth, their color of skin, their accents, that sort of thing, then maybe we would be in much better shape now than we actually are. But we haven't. We haven't been willing to make that investment. It was easier to pass a law and say, "OK, it's fixed."

What was Howard Beach but a group of black people whose car broke down in a white part of town? What was the murder of Yusuf Hawkins? A black man who was in a white neighborhood and somebody heard that he might be going out with a white woman. A couple of weeks ago on NPR, I heard about a black couple driving home from the movies, driving through a white neighborhood and having cans of rotten vegetables thrown at their car. And we say, oh God, these sorts of things don't happen where I live; they don't happen in Iowa City; they don't happen. Well, those things may very well happen in Iowa City, but you don't hear about them for whatever reasons.

You talk to black students and you discover that there may be things which you did in all innocence, things which you didn't think were harmful or hurtful at all, and they really are tremendously harmful or tremendously hurtful. I had a black student tell how she is here on academic scholarship and people will immediately ask what sport does she play. She finds that very hurtful. Now I am sure that the people asking that question didn't mean to be hurtful, didn't see their behavior as racist, but the automatic assumption that black scholarship equals athlete is a racist assumption. A lot of our trouble is that when we think about racism, we think about lynching; we think about burning crosses; we think about writing nasty graffiti on people's houses.

It strikes me that the form that we already have set up for doing the kind of work that we really need to do, if we are going to create an egalitarian nation, is already set up for us in the school system. It's in the colleges; it's in the universities.

What has been your interaction with the student body here?

I feel like I have had a lot of engagement with the students here. They have been very lively, engaged, and interested, gratifyingly interested in learning some of the things that I know and that I am interested in teaching. And that has been fun. You can also talk about a response that has been overwhelmingly positive. I am teaching a course on black women writers which is closed-it has thirty people in it-and it is gratifying to know that there is that kind of interest. But with thirty 
people . . . it is very difficult to be able to get through the amount of material that I want us to be able to get through. The Afro-American world studies faculty are intensely overworked. You have the students who have the interest, but you don't have the personnel. It's a different kind of frustration than when you're trying to start a program and nobody's interested and nobody wants to take the courses.

Speaking of personnel, I remember hearing a very sensitive and committed white male talking about how could he teach Toni Morrison. He was concerned about how the translation of Toni Morrison through him to his students inevitably whitewashes her literature. How do you respond to the problem of white people in general teaching black women writers?

I think that a good teacher can teach anybody anything. It has to do with your preparation. It always strikes me as funny-a perverse kind of humor, but it's funny. Somehow there is this assumption that all black people can teach black things. You're a black woman, you can teach Toni Morrison. Well, maybe yes, maybe no.

My immediate response to him was, "Then I certainly cannot teach Shakespeare."

It doesn't seem to bother twentieth-century white men that they're teaching a seventeenth-century white male. The seventeenth and twentieth centuries are very different. Cultural realities are very different. If you're going to be a good seventeenth century scholar, you are going to have to immerse yourself in the period. You're going to have to learn about the author. You're going to have to learn about where he lived, whom he interacted with, what the values of the period were, what were the things he did, what were the things you weren't supposed to do, what he was responding to. Was he reacting against something; was he consciously trying to change a tradition? All of these things are things that you learn as preparation to teach.

You can learn all of these things about Afro-American culture, too, and you can teach them. Anybody who teaches anything brings to bear his or her personal experience, but the reality of professional training is that you learn what it is that you need to know to teach the literature. Then, if you don't know it about a particular text that you want to teach, you go out and find it.

How should black women writers be integrated into courses? In the English department here, courses like these geared towards women of color are almost 
always undergraduate level courses. What do you think the message is that's projected by having them only on the undergraduate level? It would seem ironic since the emphasis now is on people coming out with PhDs in these areas.

Well, I'm not sure what it says. It may simply say that they don't have anybody who is qualified in terms of a degree to teach them at the graduate level. [It may] speak to a lack of personnel. They don't have the people to have two separate courses, but they have a person who could do one course. And so they sort of muddle along in that regard. But it's no less true that at certain institutions things are not granted graduate course status, because they are just not considered serious.

But in terms of integrating the writers into traditional courses or into the canon, [that's] a question that is probably both easy and difficult, or has easy and difficult solutions. The easy solution is you're teaching American literature, and African-American writers, as the name implies, are in themselves American. Taking the historical approach, the thematic approach, the regional approach, whatever, you slip them in where they belong.

I use as an example the experience of a colleague of mine who was teaching Southern literature. He had a student come to him saying, "I'm enjoying the course a lot, the readings are really interesting, but I just have to ask you, why are we reading these black authors? This is a course in Southern literature. It's not a course in black literature." And the poor student-poor in the sense that he probably felt that my friend's response was wholly inappropriate to the nature of the question - was treated to a somewhat impassioned lecture about the nature of life in the South: these blacks were themselves Southern; the Southern culture would not exist as it had existed without the plantation system, without the slave system; these black Southern writers were black and Southern just as these white Southern authors were white and Southern; if you were talking about Southern literature, it was ridiculous, it was ludicrous to segregate them according to color. But clearly the student, perhaps by virtue of the way that his education had been structured, thought about Southern writers and African-American writers as two wholly separate and separable categories, because that's the way they had always been presented.

I have to admit, when I think about Southern writers I think of Flannery O'Connor, Faulkner, Walker Percy.

It has a lot to do with the categories that you were taught. And that is not going to change until you have a whole generation or several 
generations of people who, when they were taught Southern literature, were taught Flannery O'Connor and William Faulkner and Charles Chesnutt, maybe, and maybe Toni Morrison before she moved to Ohio. Alice Walker is certainly a Southerner. So that would be the list of names they come up with. So where do you get these things? You get them from the books you read, the lectures you've heard, and the teaching. What you do is you plug them in where appropriate. And there are lots of ways that can be done.

But on the other hand, maybe you were trained in your specialty in graduate school in Southern lit., but all the seminars you took just had these white men. It's only fairly recently that when you start listing Southern writers that you could list Flannery O'Connor and Carson McCullers and Eudora Welty, because the women were shoved off into their own category. So what that means is that this person who's been this specialist in Southern literature for years and years, what he or she's going to do is a lot of work, because they're going to have to learn all these things about these writers to contextualize them. Half the work is already done if they know a lot about the South, but there's still the other half. There is the chance that your scholarship is going to be challenged because it is non-traditional, and for many people non-traditional means not serious or not worthy. If you're overworked already or you're pressed into writing books, whatever, then maybe that's a chance you don't want to take. By the time you have tenure, maybe the idea is gone, if it ever occurred to you.

It means a lot of serious work. It means questioning what you have been taught. If you're in the inclusion/exclusion mindset, then to add anybody new necessarily means to throw somebody out. It's not to say that that person is unworthy. Maybe it is to say that we need to re-think the whole way we articulate education. We must admit that it is no longer possible to master everything, that there is too much. But what it is possible to do is to give people a framework, guidelines, teach them analytical skills, teach them how to teach themselves, and go on from there.

But you started out with the simple question of how to integrate Afro-American writings into the teaching of American literature and the next thing you know you've got to restructure your whole conception of a liberal arts education. And that's a hell of a lot of work! It may seem easier to say, "Ah, let's just create another course. [There] can be an elective in Afro-American literature." 
Barbara Smith ended her essay "Towards a Black Feminist Criticism" (1972) with: "I finally want to express how much easier my sleeping and my waking hours would be if there were one book in my existence which would tell me something specific about my life, one book based in black feminist and black lesbian experience, fiction or non-fiction, just one work to reflect the reality that I and the black women whom I love are trying to create. When such a book exists each of us will not only know better how to live but how to dream." I love that ending.

It's a great ending. It's also very true.

Is it true anymore?

It's true there are a lot of books, but who's going to read them? We go to the movies; we have VCRs in our homes; we play video games. For a lot of people the only novels that they will read are the novels that they are made to read in school. It is certainly true that there are more books. Toni Morrison always says that she writes the stories that she wanted to read and they weren't out there for her. Maybe there does exist the book that Barbara Smith wanted. For a lot of us, though, we come into contact with these books when we are already grown up. The earliest works of Morrison and Walker, written in the seventies, I, as a voracious reader, didn't find out about until some years later. These were certainly not things I was going to be exposed to in high school or grade school.

When Henry Louis Gates was here, he told us that a survey of the reading lists used in high schools across the country usually turned up two people of color, and, probably, they were Ralph Ellison and Richard Wright. So you don't get that much that little Afro-American women are going to connect with. So it is still not happening.

We have this sense that there's been this tremendous explosion. You even have people saying that the only people getting published anymore are black women. But scan the best-seller lists. What are people reading? The latest Danielle Steele, the latest Judith Krantz, the latest Tom Clancy. I have nothing against these books, personally, but that's not the book Barbara Smith is looking for. [Her experience] wasn't validated, because people didn't write about it or people didn't publish books about it.

Or if they did you had no idea where to find them. 
Now, if your name is not Toni Morrison, Alice Walker, or Gloria Naylor, or a few others, you are still going to have a hell of a time getting a book published. I think sometimes the most serious damage that can be done to any kind of movement to uplift an oppressed people is that when the fad hits and there are a few people who are very, very, visible, there's a tendency to say, "Ah. It's fixed." We still have a long way to go. There are more books out there. The situation is perhaps not nearly as dire as it was when Barbara was growing up. But for African-Americans, depending on where they live, who their teachers are, and what their family values are, even though the books exist, they may not have access to them.

It's still a reality that when I sit down to teach a course on black writers I sit down with a huge list of books that I would like to teach, because I know that half of them won't be in print. Of the ones that are in print, a third to one half will be available only in very expensive hardback editions. So finally I'll get down to the short list of what you can get in paperback. And that's what I teach. It's still difficult. I think that things are better than they were when Barbara was writing that essay, but we're still not there yet.

Obviously, Alice Walker has had a lot of influence on you. What other writers have been particularly influential?

Oh, there are lots of people. I'm very fond of novels. Of the people who are writing now, I am tremendously fond of Walker, also of Toni Morrison, who I think is just a splendid writer, one of the best writers I've read in English, certainly one of the best writers writing in English these days. I've just finished reading Salman Rushdie's-well, the lecture he would have given had he been able to give it in person - "Is Nothing Sacred," which is a tremendous text. I like a lot of Latin American writers. I am particularly fond of a Brazilian woman-she's dead now-Clarice Lispector. She is really a marvelous writer. There is a great book entitled Petals of Blood by Ngugi. Amongst Americans, I'm very fond of Henry James. Proust is one of my favorite authors. I love Jane Austen. In fact, I try to reread Jane Austen every year if I get the chance. I like a lot of French novels from the nineteenth and twentieth century. Beckett is also high on my list of writers. It is a grave disappointment to me that I never got a chance to meet him before he died. These writers are people for whom I have tremendous personal and professional admiration. These are people whom I like to teach and I like to read. 
I do think that the nineteenth century was kind of the high point of the novel. I really love Jane Eyre. I like George Eliot a lot. A friend of mine said that that was a sign of the essential perversity of my nature. I think Daniel Deronda is a wonderful book. He feels that reading Daniel Deronda is one of the worst forms of torture. But, on the other hand, I don't like Melville, so I'm redeemed in his eyes. I think Melville is incredibly tedious, and I would say the same for Dickens as I cast out the old masters right and left.

What do you think of Wuthering Heights? I see a lot of similarities in prose style between Emily Bronte and Toni Morrison. I think they're both very lyrical.

I've never really thought of Wuthering Heights as a lyrical kind of text, but that's an intriguing comparison. You know that Morrison herself was greatly influenced by Faulkner. One of the things I see as I have taught the two of them together now is that you can really see the way she's influenced by him. I suppose I could see how Wuthering Heights might be seen as lyrical-it takes you out of yourself. And they're both very intense writers. I'd have to think about that for awhile.

Who else? I'm very fond of Jessie Fauset, who's somebody who has been out of print for a long time. She's a black woman who wrote during the Harlem Renaissance. One of her novels is back in print. I'm teaching it this summer, in fact. But she's tremendous, very Austenian in terms of style, makes great use of satire, writes these page-turning kinds of novels. They're sort of: Well, I'll just read one more chapter, and then I'll grade those papers. And then a chapter later: Well, I'll just read one more chapter, and then I'll grade those papers.

Well, I'm almost to the end of the book...

Well, I'm almost to the end, and it's only two o'clock, and it's going to take me awhile to get to sleep, so I'll just read that. [laughter] 
